ISSN : $1225-9918$

\title{
The Roles of Phytohormones and AtEXPA3 Gene in Gravitropic Response of Arabidopsis thaliana
}

Hye-Sup Yun', Yew Lee ${ }^{2}$ and Seong-Ki Kim*

${ }^{1}$ Department of Life Science, Chung-Ang University, Seoul 156-756, Korea

${ }^{2}$ Department of Biological Science and Technology, Yonsei University, Wonju 220-710, Korea

Received February 7, 2011 /Revised April 19, 2011 /Accepted June 24, 2011

\begin{abstract}
We focused on relationship between phytohormones and AtEXPA3 gene in gravitropic response of $A$. thaliana. RT-PCR analysis shows that AtEXPA3 was highly expressed in actively developing tissues such as leaf, rosette, root and flower tissues. AtEXPA3 gene expression was enhanced by gravistimulation, BR and IAA. Furthermore, decreased gravitropism was observed when treatment of AVG, an ethylene biosynthetic inhibitor, suggesting that ethylene has a gravistimulating effect itself as well as BRs and IAA. Inhibition of gravitropism in AtEXPA3 RNAi mutant suggests that BR, auxin and ethylene are playing roles as regulators of AtEXPA3. In addition, altered gravitropism in BRs signaling mutant (decreased in bri1-301, bak1, and increased BRI-GFP) indicated that BRs signaling mediated the gravitropism. In conclusion, gravitropic responses of Arabidopsis root resulting from root growth were mediated by increased expression of AtEXPA3 gene, which is stimulated by phytohormones.
\end{abstract}

Key words : Brassinosteroids, expansin, gravitropism, BRs signaling, Arabidopsis thaliana

\section{서 론}

식물 세포의 생장과 분화는 필연적으로 세포벽 생장의 정확 한 공간적 그리고 시간적 경향에 의존하며, 이러한 경향은 각 각의 세포 형태를 조절하는데, 이 과정에 세포벽의 일차적인 loosening agent로서 세포벽의 주요 구조적 구성성분의 가수 분해 없이 신장을 유도하는 expansin이 알려져 있다 $[8,9,27]$. Expansin은 세포벽의 세포벽의 신장을 유도하는 세포생장의 조절물질로서, leaf primordia의 초기 발생과 fruit softening $[5,13,25]$, 식물의 생식과 세포벽 분해에 관여하며[4] auxin에 의해서도 발현양이 조절되는 것으로 알려져 있다[16]. 또한 세 포벽의 이차적인 loosening agent로는 endoglucanase, xyloglucan endotransglycosylase (XET), pectinase, hydroxyl radical 등이 보고 되었으며[22,23], 이중 endoglucanase는 glucan 의 glucosidic bond를 가수분해하는 효소로, 이 또한 auxin에 의해 활성이 촉진되는 것으로 알려져 있다[14]. 이러한 세포벽 의 일차 그리고 이차적인 loosening agent의 활성은 세포벽 $\mathrm{pH}$ 의 변화, ligand의 분비, 그리고 기질의 분비에 의해 조절된 다[10,11].

현재까지 식물체에서 동정된 expansin 유전자는 multigene family로 존재하며 구조적 유사성에 따라 $a, \beta, \gamma, \delta$ 의 4가지 그룹으로 나눌 수 있다[20,26]. 이렇듯 다양한 expansin 유전자에 대한 기능적인 연구를 통해 expansin이 식물 호르몬 에 의해 발현과 활성이 특이적으로 조절될 가능성이 제기되었

*Corresponding author Tel : +82-2-820-5210, Fax : +82-2-816-8134

E-mail : skkimbio@cau.ac.kr
으며, 그 결과 토마토의 하배축에서 LeEXPA2의 발현이 auxin 에 의해 조절되며, 굴중성 자극이 있을 경우 세포신장이 활발 한 부위에서 크게 증가되는 것이 알려졌다[1]. 또한 벼의 절간 신장에 gibberellin이 expansin의 활성을 조절하며, cytokinin 과 ethylene 또한 expansin의 발현을 조절하는 것으로 알려졌 다[2,4,12]. 이러한 결과는 식물의 생장과 분화를 조절하는 식 물 호르몬이 신호전달 과정을 통해 최종적으로 활성발현과 변화를 유발하는 표적 단백질 중의 하나로 expansin을 이용하 는 것을 의미한다.

애기장대의 expansin 유전자는 $a$ 형의 expansin $(E X P A)$ 이 26 개, $\beta$ 형이 8 개, $\gamma$ 형이 2개가 확인되었으며, 2 개의 pseudogene을 포함해 모두 38개의 expansin 유전자가 존재하는 것으 로 알려졌다[19]. 이러한 expansin 유전자 중에서 일부의 $a$ 형 expansin의 기능만이 알려졌으며, 이중 AtEXPA7과 AtEXPA18 유전자는 뿌리털에서 주로 발현하며, auxin과 ethylene에 의해 특이적으로 발현이 조절되어 뿌리털 발생에 관 여하며, $A t E X P A 10$ 유전자는 잎의 생장과 화탁의 탈리에 관여 하는 것으로 알려져 있다[3]. 또한 $A t E X P A 5$ 유전자는 뿌리에 서 brassinosteroids (BRs)에 의해 발현이 특이적으로 조절되 며, 뿌리의 생장에 관여하는 것으로 알려져 있다[18].

본 연구에서는 애기장대의 BRs-insensitive mutant를 이용 하여 $\mathrm{BRs}$ 의 신호전달 과정과 뿌리의 굴중성 작용기작과의 관 계를 알아보고자 하였으며, microarray를 통해 중력자극에 의 해 발현이 증가되는 것으로 알려진 $A t E X P A 3$ 유전자가 $\mathrm{BRs}$ 의 신호전달 과정을 통해 발현되는지를 알아보고자 하였다. 또한 애기장대를 이용하여 RNA interference (RNAi)를 이용한 $A t E X P A 3$ 의 knockout 돌연변이를 제작함으로써 뿌리에서의 
$A t E X P A 3$ 유전자의 굴중성 반응과 함께 $\mathrm{BRs}$ 와의 작용을 알아 보고자 하였다.

\section{재료 및 방법}

\section{식물재료}

애기장대(Arabidopsis thaliana)는 야생형으로 Col-0 (Columbia-0)를 이용하였으며, 애기장대의 BRs 관련 mutants (bri1-301, bak1, BRI-GFP)는 모두 University of Michigan (Ann Arbor, MI)의 Jianming Li로부터 공여 받았다.

\section{애기장대 종자의 생육}

돌연변이체를 포함한 애기장대 종자는 $70 \%$ ethanol과 bleach solution (30\% clorox, $0.025 \%$ Triton X-100)을 사용하 여 표면 소독한 후, $4^{\circ} \mathrm{C}$, 암조건에서 2 일간 춘화 처리하여 사용 하였다. 춘화처리 된 종자는 굴중성 반응과 길이를 측정하기 위해 MS ( $1 \%$ sucrose, $0.8 \%$ phytagel) 배지에서 생육하였다.

\section{호르몬 처리 및 굴중성 반응과 길이 측정}

$\mathrm{MS}$ 배지에 BL과 IAA를 처리한 후, 종자를 일렬로 심어, growth chamber에서 수직으로 5 일 또는 10 일간 생육한 것을 굴중성 반응과 길이 측정에 사용하였다. RT-PCR을 통한 유전 자의 발현 분석을 위해서는 호르몬을 처리하지 않은 MS 고체 배지에서 5일간 생육한 뒤, 새로운 액상 MS 배지에 각각의 호르몬을 처리한 후, 개체를 액상 MS 배지에서 1시간 처리하 였다. 이후 실험에 따라 뿌리와 자엽을 분리하여 total RNA를 뽑아 RT-PCR에 사용하였다. 굴중성 반응과 길이 측정은 digital camera (SANYO, VCTAZ1)를 이용하여 촬영한 뒤, 측정은 Image-Pro Plus 프로그램(Yongma)을 이용하여 각도와 길이 를 측정하였다.

\section{AtEXPA3 RNAi knockout 돌연변이체의 제작}

RNAi를 위한 DNA construct를 제작하기 위하여, $A t E X P A 3$ 의 3개의 exon 중에서 exon1 (E1)과 intron1 (I1)을 표적으로 하여 primer를 제작하였다. E111의 primer는 $5^{\prime}$ 에 XbaI site와 BamHI site를 각각 첨가하여 5'-tctagaCTG CGTTTAGGGTCGGCTT-3'과 5'-ggatccTAGCAAAACCCCA $-3^{\prime}$ 를 제작하였으며, reverseE1 (RE1)의 primer는 $5^{\prime}$ 에 BamHI site와 SacI site를 각각 첨가하여 5'-ggatccATTGTGCCGGAG3'과 5'-gagctcGACTGCGTTTAGGGTCGGCTT-3'를 제작하 여, Col-0에서 추출한 DNA를 이용하여 PCR을 이용하여 증폭 하였다. 이후 양방향 염기서열 분석에 의해 E1I1-RE1의 construct를 확인한 뒤 pBI121 vector에 삽입하였다. E1I1-RE1/ pBI 121vector 이후 electroporator를 이용하여 agrobacterium 에 형 질전환 한 후, floral dipping방법[6]을 이용하여 애기장 대에 형질전환 하였다. 이후 실온에서 이틀간 애기장대(T0)를
말린 후, growth chamber (light $16 \mathrm{hr}, 22^{\circ} \mathrm{C} /$ dark $8 \mathrm{hr}, 20^{\circ} \mathrm{C}$, 습도 $70 \%)$ 에서 생육하여 종자(T1)를 얻었다.

얻어진 애기장대의 종자(T1)는 상기의 방법으로 표면 소 독 후, 춘화 처리하여 kanamycin $\left(50 \mathrm{\mu g} \mathrm{ml}^{-1}\right)$ 이 포함된 MS ( $1 \%$ sucrose, $0.8 \%$ micro agar) 배지가 고형화된 사각 petri-dish $(125 \times 125 \times 20 \mathrm{~mm})$ 에 일렬로 심은 뒤, growth chamber에서 생육하여 kanamycin에 저항성을 나타내는 개체를 선별하였으며, 선별된 개체는 peat moss와 vermiculite를 1:1로 혼합하여 만든 화분(pot)에 옮겨 심어 다음 세대의 종 자(T2)를 얻었다. 각각의 개체에서 얻어진 종자는 다시 kanamycin이 포함된 멸균된 1× MS 고체 배지에서 저항성을 갖는 개체만을 화분에 옮겨 얻어진 종자(T3)만을 RNAi mu$\operatorname{tant}$ 로 실험에 사용하였다.

\section{$\mathrm{RT}-\mathrm{PCR}$ 을 이용한 AtEXPA3의 발현 조사}

5 일 또는 10 일간 생육된 애기장대 seedling을 액체 질소에 바로 얼린 후 cold pestle과 mortar를 이용해 분쇄한 뒤 Tri reagent를 이용하여 total RNA를 추출하였다. 추출한 RNA를 역전사 시킨 후 얻어진 cDNA와 $A t E X P A 3$ 유전자의 $5^{\prime}-\mathrm{GTC}$ CCTATCCAATACACATCTCT CTCTCT-3'와 5'-TTACACG GTCCATTCGACTCGATCACTGA-3'를 각각 forward와 reverse primer로 사용하여 발현 양상을 조사하였다.

\section{결 과}

애기장대 뿌리에서의 brassinolie 처리에 의한 굴중성 반응

다양한 농도의 brassinolide $\left(\mathrm{BL}, 10^{-10} \mathrm{M}-10^{-7} \mathrm{M}\right)$ 을 처리한 MS 고형 배지에서 5일간 수직으로 생육한 $\mathrm{Col}-0$ 를 6시간 동안 중력자극을 주어 뿌리의 꺾인 정도를 측정하였다. 그 결과, 외부 처리한 $\mathrm{BL}$ 의 농도가 증가할수록 뿌리의 굴중성 반응이 촉진되는 결과를 확인하였다(Fig. 1)

BRs-insensitive 돌연변이체를 이용한 애기장대 뿌리의 굴중성 반응

외부에서 처리한 $\mathrm{BL}$ 에 의해 애기장대 뿌리에서도 굴중성 반응이 촉진되고 있음이 확인되어, BRs-insensitive 돌연변이 체를 이용하여 애기장대 뿌리의 굴중성 반응을 조사하였다. BRs의 receptor로서 알려진 BRI1 유전자의 변이에 의해 BRs를 인식하지 못하는 bri1 돌연변이체 중에서 bri-301 및 BRI1과 상호작용하여 BRI1을 인산화시키는 것으로 BRs의 신호전달 에 관여하는 BAK1 유전자의 돌연변이체인 bak1, 그리고 BRI1 의 promoter와 유전자를 GFP (green fluorescent protein) 유 전자에 결합되어 야생형보다 2배 많은 BRI1을 가지는 BRI-GFP 돌연변이체를 이용하여 MS 고형 배지에서 5 일간 수 직으로 생육하여 6시간 동안 중력자극을 주어 뿌리의 굴중성 반응을 측정하였다. 그 결과, bri-301 돌연변이체는 Col-0와 비 


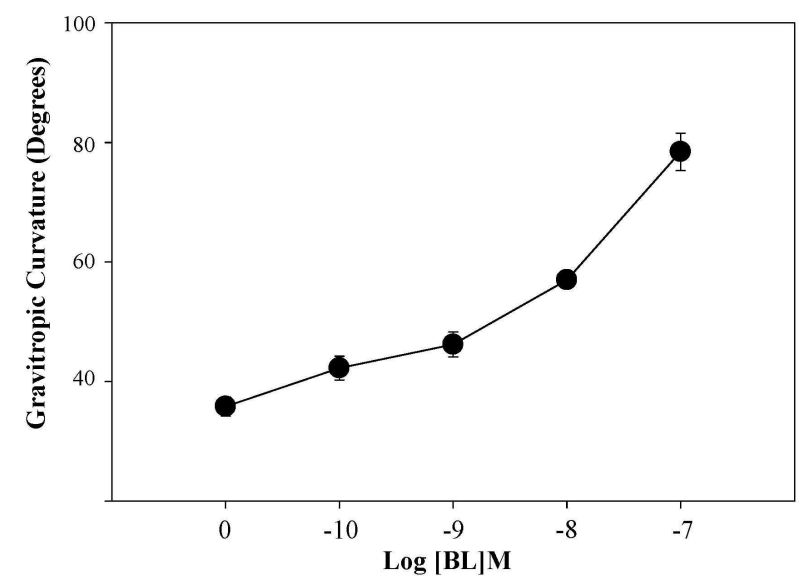

Fig. 1. Dose-response for BL effects on gravitropic response in Arabidopsis roots. Bars indicate standard errors.

교하여, 약 $24 \%$ 의 굴중성 반응이 억제되었으며, bak1 돌연변이 체는 약 $14 \%$ 의 굴중성 반응이 억제되었다. 그러나 BRI-GFP의 경우 약 $28 \%$ 의 굴중성 반응이 촉진되었다(Fig. 2). 이러한 결과 는 굴중성 반응에 있어 외부에서 처리 한 BL이 작용할 때, BRs 의 receptor를 통한 $\mathrm{BL}$ 의 신호전달 과정을 통해 굴중성 반응 효과가 나타나기 때문인 것으로 생각된다.

또한 BRs-insensitive 돌연변이체에 ethylene (0.001 ppm)과 ethylene 생합성 억제제인 AVG $\left(10^{-2} \mathrm{M}\right)$ 를 6시간 동안 처리하 여 굴중성 반응을 조사하였다. 그 결과 ethylene을 처리하였을 경우, 야생형을 포함한 bri-301, BRI-GFP, bak1 돌연변이체에서 각각 $15 \%, 17 \%, 6 \%$ 그리고 $20 \%$ 의 굴중성 반응이 촉진되었으 며, AVG를 처리하였을 경우에는 야생형을 포함한 bri-301, BRI-GFP, bak1 돌연변이체에서 각각 $55 \%, 5 \%, 70 \%$ 그리고 $53 \%$ 의 감소된 굴중성 반응이 나타났다(Fig. 3). 이러한 결과는 뿌리에서의 굴중성 반응은 내생의 BRs가 신호전달 과정이 정 상적으로 이루어지지 않더라도 외부에서 처리 한 ethylene에

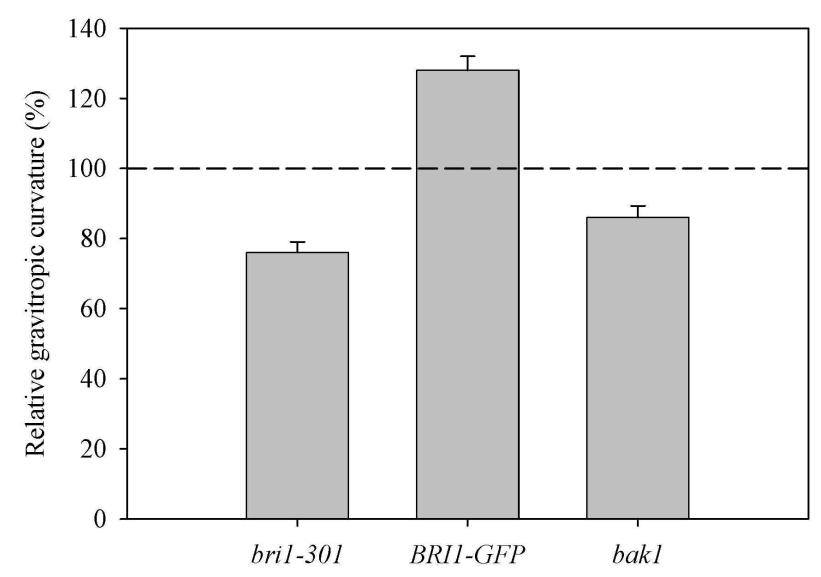

Fig. 2. Gravitropic response on the roots of wild type (Col-0), bri-301, BRI-GFP and bak1. Dashed line indicates Col-0. Bars indicate standard errors.

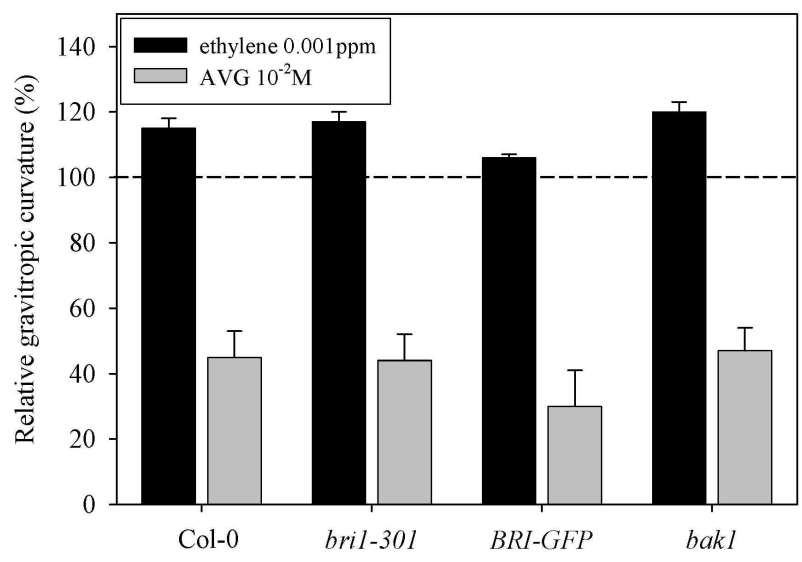

Fig. 3. Effect of ethylene $(0.001 \mathrm{ppm})$ and AVG $\left(10^{-2} \mathrm{M}\right)$ on the roots gravitropic response of Col-0, bri-301, BRI-GFP and bak1. The roots were gravistimulated by placing them horizontally in the presence or absence of ethylene and AVG for $3 \mathrm{hr}$ in the light at room temperature. Dashed line indicates ethylene and AVG untreated plants. Bars indicate standard errors.

의해서도 굴중성 반응이 촉진되며, 뿌리에서의 ethylene 생합 성이 $\mathrm{AVG}$ 를 통해 억제되었을 경우 상당한 굴중성 억제 효과 가 나타나 뿌리의 굴중성 반응이 다양한 식물 호르몬에 의해 조절되는 것으로 생각된다.

\section{AtEXPA3 유전자 발현}

중력자극에 의해 발현이 증가되는 것으로 알려진 $A t E X P A 3$ 유전자의 조직 별 발현양상을 알아보기 위해 30 일 동안 growth chamber에서 생육된 Col-0를 대상으로 RT-PCR을 통 해 $A t E X P A 3$ 의 발현을 조사하였다. 그 결과 $A t E X P A 3$ 유전자 의 발현이 애기장대의 모든 부분, 즉 줄기의 잎, 근출엽(rosette leaf), 뿌리, 꽃, 줄기에서 발현되는 것이 확인되었다(Fig. 4A). 특징적인 것은 이러한 $A t E X P A 3$ 유전자의 발현이 성체시기에 뿌리에서 좀더 강하게 발현되었으며, 어린 식물을 대상으로 5 일과 10 일 정도 키운 애기장대를 뿌리와 자엽으로 나누어

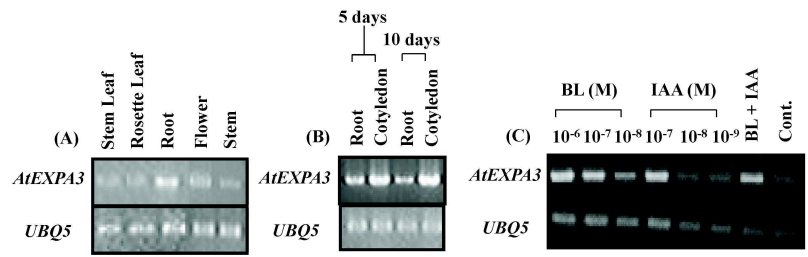

Fig. 4. RT-PCR analysis for AtEXPA3 transcripts in Arabidopsis. Total RNA was prepared from various tissues and conditions. Tissue-specific expression of AtEXPA3 gene in Arabidopsis (A). Expression of AtEXPA3 gene of cotyledon and root of young Arabidopsis (5 days and 10 days) (B). Expression of AtEXPA3 gene induced by BL and IAA in the roots of young Arabidopsis (5 days) (C). 
$A t E X P A 3$ 의 발현을 조사하였을 경우에는 성체시기에서 나타 나는 것과는 달리 뿌리 보다는 자엽에서의 발현이 강하게 나 타났다(Fig. $4 \mathrm{~B})$. 이러한 결과는 $A t E X P A 3$ 의 발현이 식물체의 모든 부분에서 발현되며, 식물의 생장이 활발한 어린 시기에 는 뿌리보다는 자엽에서 활발히 발현되어 잎과 줄기의 생장에 관여하며, 생장이 더 이상 진행되지 않은 성체시기에서는 그 발현이 점차 줄어드는 것으로 사료된다. 이와는 달리 지속적 인 생장을 하는 뿌리에서는 성체시기에도 $A t E X P A 3$ 의 발현이 감소하지 않는 것으로 사료된다.

애기장대 뿌리에서의 $\mathrm{BL}$ 과 IAA에 의한 AtEXPA3의 발현 애기장대의 어린 뿌리에서의 발현이 확인된 $A t E X P A 3$ 유전 자를 대상으로 BL과 IAA에 의한 발현 정도를 알아보기 위하 여 5일 동안 생육된 Col- 0 를 BL $\left(10^{-6} \mathrm{M}-10^{-8} \mathrm{M}\right)$ 과 IAA $\left(10^{-6}\right.$ $\left.\mathrm{M}-10^{-8} \mathrm{M}\right)$ 의 농도를 달리하여 처리한 액상 MS 배지에서 1 시간 동안 배양한 후, 뿌리와 자엽을 분리하여 뿌리에서 total $\mathrm{RNA}$ 를 추출하여 RT-PCR을 통해 유전자의 발현 정도를 조사 하였다. 그 결과 $\mathrm{BL}$ 과 $\mathrm{IAA}$ 의 농도가 증가함에 따라 AtEXPA3 의 발현이 증가됨이 관찰되었다. 그러나 $\mathrm{BL}\left(10^{-7} \mathrm{M}\right)$ 과 IAA $\left(10^{-8} \mathrm{M}\right)$ 를 함께 처리하였을 경우에는 BL과 IAA의 상승효과 로 인한 발현 증가는 나타나지 않았다(Fig. $4 \mathrm{C}$ ).

BRs-insensitive 돌연변이체 뿌리에서 굴중성 반응에 의 한 AtEXPA3 유전자의 발현

애기장대의 뿌리에 $\mathrm{BL}$ 을 처리했을 때, 굴중성 반응이 촉진 과 $A t E X P A 3$ 유전자의 발현이 증가되는 결과를 통해 $\mathrm{BRs}$ 의 신호전달 과정이 굴중성에 관여할 가능성을 예상하였다. 이에 BRs-insensitive 돌연변이체를 이용하여 내생의 BRs가 신호전 달 과정을 통해 $A t E X P A 3$ 유전자의 발현을 조절하는지를 알아 보기 위해 BRs-insensitive 돌연변이체에 중력자극을 1 시간 처 리하여 $A t E X P A 3$ 의 발현을 조사하였다. 그 결과, $\mathrm{Col}-0$, $B R I-G F P$ 에서 AtEXPA3의 발현이 증가된 반면, bri-301, bak1 돌연변이체에서는 $A t E X P A 3$ 의 발현이 증가하지 않았다(Fig. 5). 이러한 결과는 중력자극에 의한 $A t E X P A 3$ 의 발현이 BRs의 신호전달 과정을 통해 조절되는 것이라 하겠다.

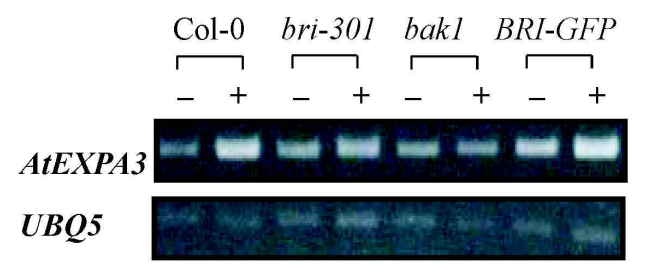

Fig. 5. RT-PCR analysis for AtEXPA3 transcripts of bri-301, bak1 and BRI-GFP. The roots with $(+)$ or without $(-)$ were gravistimulated by placing them horizontally for $1 \mathrm{hr}$. Bars indicate the standard errors.

\section{AtExpa3 knockout 돌연변이체를 이용한 뿌리의 굴중성 반응}

애기장대의 AtEXPA3 RNAi 돌연변이체를 이용하여 $A t E X P A 3$ 의 발현이 억제되었을 때, 뿌리에서의 굴중성 반응을 알아 보았다. 먼저 뿌리에서 AtEXPA3의 발현이 뿌리의 생장 에 미치는 효과를 알아보고자 뿌리의 생장을 관찰한 결과 RNAi 돌연변이체에서 $\mathrm{Col}-0$ 와 뿌리의 길이생장을 비교할 때, 약 $33 \%$ 의 길이 생장 억제효과가 관찰되었다(Fig. $6 \mathrm{~A}$ ). 또한 $\mathrm{RNAi}$ 돌연변이체는 $\mathrm{Col}-0$ 에 비하여, 측근의 형성이 뚜렷하게 관찰되었다(Fig. 6B). 이러한 결과는 뿌리에서의 AtEXPA3 유 전자의 발현이 뿌리의 생장과 측근 형성에 관여하는 것으로 뿌리의 생장에 이러한 $A t E X P A 3$ 의 발현이 중요한 역할을 할 것으로 사료된다.

$A t E X P A 3$ 의 발현이 뿌리의 굴중성과 관련하여 $\mathrm{BL}$ 과 IAA 에 의해 발현이 증가됨이 애기장대 뿌리에서 확인되어, $\mathrm{BL}$ $\left(10^{-9} \mathrm{M}\right)$ 또는 IAA $\left(10^{-10} \mathrm{M}\right)$ 를 처리한 돌연변이체와 Col- 0 를 6시간 동안 중력자극을 주어 뿌리의 굴중성 반응을 측정하였 다. 그 결과 호르몬을 처리하지 않은 AtEXPA3 RNAi 돌연변 이체는 야생형에 비해 $15 \%$ 의 굴중성 억제효과가 나타났다. 반면 BL을 처리하였을 경우에는 각각 Col-0에서 $48 \%$, RNAi 에서는 $24 \%$ 의 굴중성 촉진효과가, $\mathrm{IAA}$ 을 처리한 경우 $\mathrm{Col}-0$, $\mathrm{RNAi}$ 에서 각각 $12 \%, 3 \%$ 의 굴중성 촉진효과가 나타났다. 또 한BL과 IAA를 동시에 처리했을 경우에는 Col-0, RNAi에서 각각 $70 \%, 38 \%$ 로 굴중성 촉진효과가 나타났다(Fig. 7). 이는 AtEXPA3 유전자의 발현은 뿌리의 생장을 촉진함으로써 굴중 성 반응을 촉진시키며, 또한 $\mathrm{BL}$ 과 IAA에 의해 발현이 증가되 어 활성을 나타내는 결과라 하겠다. 그러나 AtEXPA3의 발현 이 억제된 돌연변이체에서 BL 또는 IAA를 외부 처리했을 때 그 활성이 강하게 억제되지 않고 굴중성 반응이 나타난다는 것은 $A t E X P A 3$ 이외에 $\mathrm{BL}$ 과 $\mathrm{IAA}$ 에 의한 다양한 유전자들의 발현에 의해 뿌리에서의 굴중성 반응이 조절 되기 때문이라 사료된다.

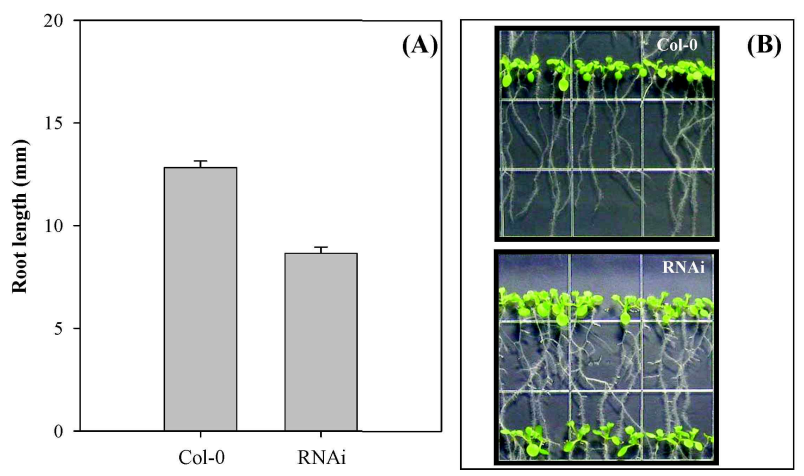

Fig. 6. Roots elongation of wild type (Col-0) and AtEXPA3 RNAi mutant (A) and their lateral root phenotype (B). Bars indicate the standard errors. 


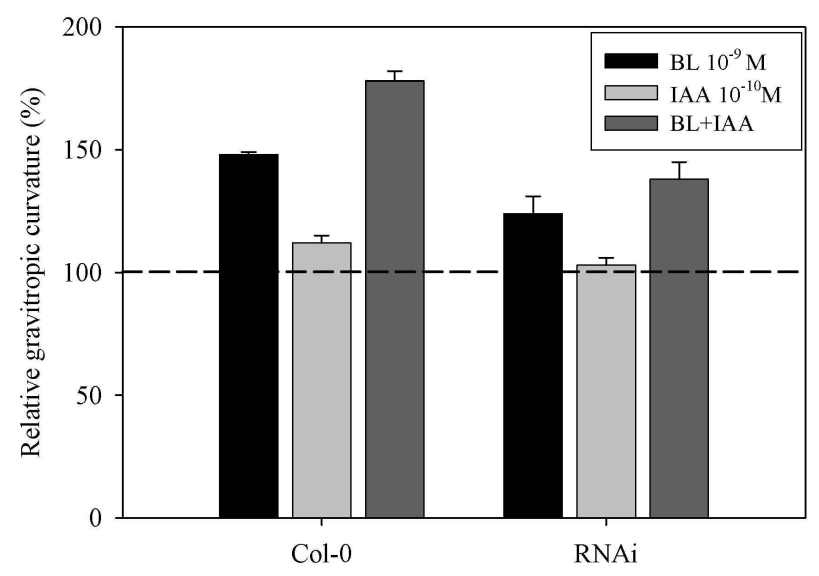

Fig. 7. Effect of BL $\left(10^{-9} \mathrm{M}\right)$ and IAA $\left(10^{-10} \mathrm{M}\right)$ on the gravitropic response of AtEXPA3 RNAi mutant. Dashed line indicates Col-0 and RNAi without hormone treatment. Bars indicate the standard errors.

\section{고 찰}

식물의 굴중성에 대한 BRs의 작용은 외부처리에 의한 BRs 의 생리활성이 조사되어 강낭콩 하배축의 굴중성을 촉진하는 것이 보고된 이후[21], 토마토의 하배축[24], 옥수수의 1차뿌리 [17]에서도 BRs에 의한 굴중성 활성이 확인되어, BRs가 식물 줄기의 굴중성 반응에 관여하는 것으로 알려졌다.

이에 본 연구에서 야생형의 애기장대 뿌리에 다양한 농도의 $\mathrm{BL}$ 을 처리하였을 때, 농도 의존적으로 굴중성 반응을 증가되 는 것을 확인 하였다. 이에 BRs-insensitive 돌연변이체를 이용 한 굴중성 반응에서 야생형 애기장대와 비교한 결과, bri-301과 $b a k 1$ 은 야생형보다 감소된 굴중성 반응을 보이며, 야생형보다 $\mathrm{BRs}$ 의 신호전달이 증가된 $B R I-G F P$ 에서는 굴중성 반응의 증 가현상이 나타났다. 이는 BRs의 신호전달 과정이 애기장대 뿌 리의 굴중성 반응을 조절하는 것으로, 뿌리가 중력자극을 받 으면 내생의 BRs의 함량을 증가시켜 BRs의 신호전달 과정을 통해 특정 유전자의 활성을 증가시킨 후, 이 유전자의 발현을 통해 굴중성 반응에 작용하는 것으로 사료된다.

또한 애기장대의 BRs-insensitive 돌연변이체에 ethylene을 처리하여 ethylene에 의한 굴중성 반응을 확인한 결과 bri-301, bak1, BRI-GFP에서 ethylene에 의한 굴중성 반응 활성이 유사 하게 나타났다. 또한 AVG를 처리하여 내생의 ethylene의 생 합성이 저해되었을 때, 굴중성 반응이 현저히 억제되는 결과 가 나타났는데, 이를 통해 ethylene 그 자체도 굴중성을 촉진 시키는 활성을 갖고 있으며, 뿌리에서의 굴중성 반응이 다양한 식물 호르몬의 상호작용에 의해 조절되리라 예상할 수 있다.

또한 본 연구에서는 expansin 유전자 중에서 중력자극에 의해 발현이 증가되는 것으로 알려진 AtEXPA3 유전자를 대상 으로 애기장대 뿌리에서의 굴중성 반응과 BRs의 신호전달 과 정과의 관계를 알아보았다. 먼저 애기장대의 조직 별
$A t E X P A 3$ 의 발현 양상을 조사한 결과 줄기의 잎, 근출엽, 뿌리, 꽃, 줄기 등 모든 조직에서 발현이 확인되며 특히 생장이 활발 한 조직에서 발현량이 높은 것을 확인하였다. Wieczorek 등 [15]은 AtEXPA3가 shoot specific expression 한다고 보고하였 지만, 최근 microarray data에서 $A t E X P 3$ 의 발현이 뿌리의 발 달 전 시기 동안 지속되고 있음을 확인하였다[28]. 이를 고려할 때, 본 연구에서 확인한 AtEXPA3의 뿌리에서의 발현은 지속 적인 뿌리생장에 반드시 필요한 것으로 생각된다. 또한 $A t E X P A 3$ 의 발현이 외부 처리한 $\mathrm{BL}$ 과 $\mathrm{IAA}$ 에 의해 증가하는 결과가 나타나 $A t E X P A 3$ 의 발현이 $\mathrm{BL}$ 과 $\mathrm{IAA}$ 에 의해 조절될 가능성이 나타났다. 이러한 결과를 통해 뿌리의 굴중성 반응 이 다양한 식물 호르몬을 통해 특정 유전자의 발현을 증가시 켜 작용하는 것으로 예상하고 이를 확인하고자 bri-301, bak1, $B R I-G F P$ 에 중력자극을 주고 $A t E X P A 3$ 의 발현을 측정하였다. 그 결과 야생형에서는 $A t E X P A 3$ 의 발현이 중력자극을 준 뿌리 에서 뚜렷한 발현 증가가 나타났으나, bri-301과 bak1에서는 중력자극을 주지 않은 뿌리와 비교할 때 뚜렷한 발현의 차이 가 나타나지 않았다. 또한 BRI-GFP에서는 중력자극을 준 뿌리 에서 뚜렷한 AtEXPA3의 발현이 확인되었는데 이러한 결과는 중력자극을 통해 내생 함량이 증가된 BRs가 신호전달 과정을 통해 $A t E X P A 3$ 유전자의 발현을 증가시켜 굴중성 반응을 나타 내는 것으로서 뿌리에서의 굴중성 반응이 $\mathrm{BRs}$ 에 의해 특정 유전자의 발현을 조절함으로써 나타나는 것이라 하겠다.

$\mathrm{BRs}$ 에 의한 발현증가가 확인된 $A t E X P A 3$ 이 직접적인 뿌리 의 굴중성 반응을 나타내는지를 알아보기 위해 RNAi 돌연변 이체를 이용하여 확인한 결과 RNAi 돌연변이체에 중력자극 이 주어졌을 때 야생형에 비해 굴중성 반응이 억제되는 결과 를 확인하였다. 또한 $A t E X P A 3$ 유전자의 결핍에 따라 뿌리의 길이와 측근의 생성이 억제되는 결과를 통해, $A t E X P A 3$ 가 굴 중성 반응뿐만 아니라 뿌리의 생장 전반에 관여하고 있음을 알 수 있었다. 또한 외부 처리한 BL 또는 IAA에 의해서 RNAi 돌연변이체에 굴중성 반응이 촉진되는 결과가 나타났다. 이러 한 결과는 세포 생장에 관여하는 다수의 expansin 중 AtEXPA3 이외에 다른 expansin 유전자와 세포 생장에 관련된 다른 유전자가 $\mathrm{BL}$ 또는 $\mathrm{IAA}$ 를 통해 굴중성 반응에 관여하기 때문인 것으로 사료된다(Fig. 8).

이상과 같이 본 연구에서는 애기장대의 BRs-insensitive 돌 연변이체를 이용하여 뿌리에서의 굴중성 반응이 $\mathrm{BRs}$ 의 신호 전달 과정을 통한 AtEXPA3 유전자 발현변화로 인해 일어남을 확인 하였다. 또한 BRs와 auxin에 의해 생합성이 증가되는 것 으로 알려진 ethylene도 뿌리의 굴중성 반응을 촉진함을 확인 하였다. 본 연구를 통해 뿌리의 굴중성 반응이 다양한 식물 호르몬, 즉 BRs, auxin, ethylene에 의해 나타나며, 또한 이러한 식물 호르몬 중에서 $\mathrm{BRs}$ 에 의해 세포 생장에 관여하는 expansin 유전자 중에서 AtEXPA3 유전자의 발현이 굴중성 반응 을 증가하는 것을 처음으로 확인하였다. 그러나 애기장대에서 


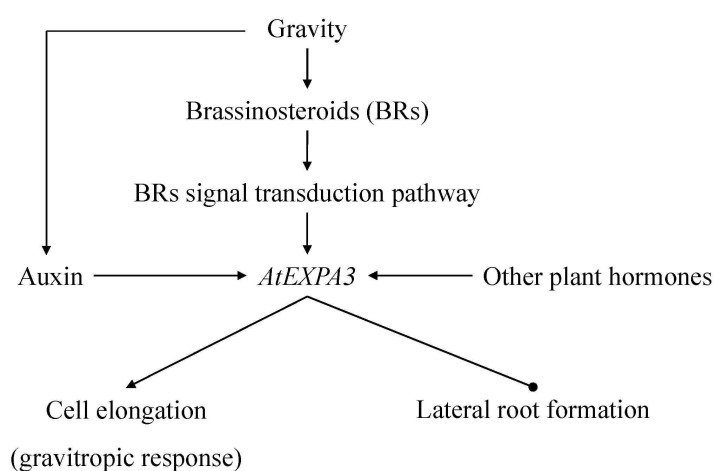

Fig. 8. Possible action mechanism of AtEXPA3 on gravitropic response through the BRs and IAA.

다수의 expansin 유전자가 존재함이 알려져 있어 AtEXPA3 이외에 다른 expansin 유전자도 BRs를 포함한 auxin과 ethylene에 의해 조절될 가능성이 있는 것으로 사료된다. 따라서 뿌리의 굴중성 반응기작을 이해하기 위해서는 굴중성 반응에 작용하는 식물 호르몬인 BRs, auxin, ethylene에 의해 발현이 조절되는 expansin 유전자를 구체적으로 선별하고 이들 유전 자의 기능과 식물 호르몬과의 상관관계를 연구하는 것이 필요 하다 생각된다.

\section{감사의 글}

이 논문은 2003년도 중앙대학교 박사후연수과정(Post-Doc) 지원사업에 의한 것임.

\section{References}

1. Catala, C., J. K. C. Rose, and A. B. Bennett. 2000. Auxin-regulated genes encoding cell wall-modifying proteins are expressed during early tomato fruit growth. Plant Physiol. 122, 527-534.

2. Cho, H. T. and H. Kende. 1997. Expression of expansin genes correlated with growth in deepwater rice. Plant Cell 9, 1661-1671.

3. Cho, H. T. and D. J. Cosgrove. 2000. Altered expression of expansin modulates leaf growth and pedical abscission in Arabidopsis thaliana. Proc Natl. Acad Sci. USA 97, 9783-9788.

4. Cho, H. T. and H. Kende. 1997. Expansins in deepwater rice internodes. Plant Physiol. 113, 1137-1143.

5. Civello, P. M., A. L. Powell, A. Sabehat, and A. B. Bennett. 1999. An Expansin gene expressed in ripening strawberry fruit. Plant Physiol. 121, 1273-1279.

6. Clough, S. J. and A. F. Bent. 1998. Floral dip: a simplified method for agrobacterium-mediated transformation of Arabidopsis thaliana. Plant J. 16, 735-743.

7. Cosgrove, D. J. 1989. Characterization of long-term expression of isolated cell walls from growing cucumber hypocotyls. Planta 177, 121-130.
8. Cosgrove, D. J. 1993. Water uptake by growing cells; an assessment of the controlling roles of wall relaxation, solute uptake and hydraulic conductance. Int. J. Plant Sci. 154, 10-21.

9. Cosgrove, D. J. 1997. Cellular mechanisms underlying growth asymmetry during stem gravitropism. Planta 203, 130-135.

10. Cosgrove, D. J. 2000. Loosening of plant cell walls by expansins. Nature 407, 321-326.

11. Cosgrove, D. J. 2000. New genes and new biological roles for expansins. Curr. Opin. Plant Biol. 3, 73-78.

12. Downes, B. P., C. R. Steinbaker, and D. N. Crowell. 1998. Expression and processing of a hormonally regulated beta-expansin from Soybean. Plant Physiol. 126, 244-252.

13. Fleming, A. J., S. McQueen-Mason, T. Mandel, and C. Kuhlemeier. 1997. Induction of leaf primordia by the cell wall protein expansin. Science 27, 1414-1418.

14. Fry, S. C. 1995. Polysaccharide modifying enzymes in the plant cell wall. Annu. Rev. Plant Physiol. Plant Mol. Biol. 46, 497-520.

15. Hruz, T., O. Laule, G. Szabo, F. Wessendorp, S. Bleuler, L. Oertle, P. Widmayer, W. Gruissem, and P. Zimmermann. 2008. Genevestigator V3: a reference expression database for the meta-analysis of transcriptomes. AdV. Bioinformatics 2008, Article ID 420747, 5.

16. Huchison, K. W., P. B. Singer, C. Diaz-Sala, and M. S. Greenwood. 1999. Expansin are conserved in conifers and expression in response to exogenous auxin. Plant Physiol. $120,827-832$.

17. Kim, S. K., S. C. Chang, E. J. Lee, W. S. Chung, Y. S. Kim, S. Hwang, and J. S Lee. 2000. Involvement of brassinosteroids in the gravitropic response of primary root of maize. Plant Physiol. 123, 997-1004.

18. Kim, T. W. 2003. Mechanism of homeostatic regulation and action of plant steroidal hormones, brassinosteroids. Ph. D Thesis, Chung-Ang University, Seoul. Korea.

19. Lee, Y., D. Choi, and H. Kende. 2001. Expansin: ever-expanding numbers and functions. Curr. Opin. Plant Biol. 4, 527-532.

20. McQueen-Mason, S. J., D. M. Durachko, and D. J. Cosgrove. 1992. Two endogenous proteins that induce cell wall extension in plants. Plant Cell 4, 1425-1433.

21. Meudt, W. T. 1987. Investigations on mechanism of brassinosteroid response. Plant Physiol. 83, 195-198.

22. Nishitani, K. 1997. The role of endoxyloglucan transferase in the organization of plant cell walls. Int. Rev. Cytol. 173, 157-206.

23. Nishitani, K. 1998. Construction and re-structuring of the cellulose-xyloglucan framework in the apoplast as mediated by the xyloglucan-related protein family-a hypothetical scheme. J. Plant Res. 111, 1-8.

24. Park, W. J. 1998. Effect of epibrassinolide on hypocotyl growth of the tomato mutant diageotropica. Planta 207, 120-124.

25. Rose, J. K. C., H. H. Lee, and A. B. Bennett. 1997. Expression of a divergent expansin gene is fruit-specific and ripen- 
ing-regulated. Proc. Natl. Acad Sci. USA 94, 5955-5960.

26. Shcherban, T. Y., J. Shi, D. M. Durachko, M. J. Guiltinam, S. McQueen-Mason, M. Shieh, and D. J. Cosgrove. 1995. Molecular cloning and sequence analysis of expansins-a highly conserved, multigene family of proteins that mediate cell wall extension in plants. Proc. Natl. Acad Sci. USA 92, 9245-9249.

27. Varner, J. E. and L. S. Lin. 1989. Plant cell wall architecture.
Cell 56, 231-239.

28. Wieczorek, K., B. Golecki, L. Gerdes, P. Heinen, D. Szakasits, D. M. Durachko, D. J. Cosgrove, D. P. Kreil, P. S. Puzio, H. Bohlmann, and F. M. W. Grundler. 2006. Expansins are involved in the formation of nematode-induced syncytia in roots of Arabidopsis thaliana. Plant J. 48, 98-112.

\section{초록 : 애기장대 굴중성 반응에 있어서 식물호르몬과 AtEXPA3 유전자의 역할}

윤혜섭 ${ }^{1} \cdot$ 이유 $^{2} \cdot$ 김성기 $^{1}{ }^{*}$

('중앙대학교 생명과학과, ${ }^{2}$ 연세대학교 생명과학기술학부)

본 연구에서는 식물뿌리의 굴중성 반응에 있어서 식물호르몬과 AtEXPA3 유전자와의 관계를 밝히고자 하였 다. AtEXPA3 유전자의 RT-PCR을 통한 발현분석 결과 잎, 근출엽, 뿌리 꽃 등 생장이 활발한 조직에서 발현률이 높게 나타났으며, 굴중성 자극과 BRs, IAA에 의해서도 발현이 증가되었다. 또한 ethylene 생합성 저해제인 AVG 를 처리하면 굴중성 반응이 현저히 억제되었는데 이는 ethylene 그 자체도 BR과 IAA처럼 굴중성을 촉진시키는 활성을 갖고 있음을 의미한다. 한편 호르몬을 처리하지 않은 AtEXPA3 RNAi mutant에서 굴중성 반응이 억제되 는 현상은 애기장대 뿌리의 생장에 관여하는 $A t E X P A 3$ 의 조절 인자로 BRs, auxin, ethylene 등의 식물호르몬이 관여하고 있음을 나타낸다. 아울러 BRs signaling mutant에서 변화된 굴중성(bri1-301, bak1에서 감소, BRI-GFP에 서 증가) 반응의 감소와 증가는 굴중성 반응이 $\mathrm{BRs}$ 의 신호전달 과정을 통하여 일어남을 의미한다. 결론적으로 애기장대 뿌리의 굴중성 반응은 식물호르몬에 의한 $A t E X P A 3$ 유전자의 발현 증가의 결과로 인해 애기장대 뿌리 의 생장이 촉진되어 나타나는 결과라 하겠다. 